dr inz. Maciej Andrzejewski

dr in.. Pawet Daszkiewicz

mgr Dawid Gallas

Instytut Pojazdów Szynowych ,TABOR”

dr hab.inż. Agnieszka Merkisz-Guranowska, prof.PP

mgr inz. Lukasz Stawecki

Politechnika Poznańska

\title{
Methods of reducing energy consumption for mass transit vehicles
}

\begin{abstract}
The paper contains basic information about the currently used methods of construction and maintenance, that result in the reduction of fuel consumption by mass transit vehicles, for both passenger and freight vehicles. Particular attention was given to solutions using hybrid systems (regenerative braking) and systems that recover energy from exhaust gas (thermoelectric generators. The economic aspects of exploitation of such vehicles associated with the proper control of drive units (i.e. eco-driving) were also considered.
\end{abstract}

\section{Sposoby zmniejszenia energochłonności ruchu pojazdów transporty masowego}

\begin{abstract}
Artykut zawiera podstawowe informacje dotyczqce aktualnie stosowanych metod konstrukcyjnych i eksploatacyjnych, powodujacych zmniejszenie zużcia paliwa przez pojazdy transportu masowego, przeznaczone zarówno do przewozów pasażerskich, jak i towarowych. $W$ szczególności zwrócono uwagę na rozwiqzania wykorzystujace układy napędu hybrydowego (hamowanie rekuperacyjne) oraz uklady odzysku energii ze spalin silnikowych (generatory termoelektryczne). Uwage zwrócono również na aspekty ekonomicznego użytkowania pojazdów zwiazane z właściwym sterowaniem jednostkami napędowymi (tzw. eko-jazda).
\end{abstract}

\section{WPROWADZENIE}

W ostatnim czasie Komisja Europejska przyjęła wszechstronną strategię (Transport w roku 2050) zmierzającą do ustanowienia konkurencyjnego systemu transportu, służącemu zwiększeniu mobilności, pokonaniu głównych przeszkód w najważniejszych obszarach branżowego rozwoju oraz pobudzeniu wzrostu zatrudnienia $\mathrm{w}$ tym sektorze gospodarki. Przyszłościowe plany mają na celu redukcję o $60 \%$ łącznej emisji dwutlenku węgla w sektorze transportu do roku 2050 oraz zdecydowane zmniejszenie zależności Europy od importowanej ropy naftowej.

Osiagnięcie ww. celów wymaga dogłębnej transformacji obecnych systemów transportu. Do najważniejszych szczegółowych celów na rok 2050 należą:

- miasta wolne od pojazdów o napędzie konwencjonalnym,

- redukcja emisji towarzyszących transportowi morskiemu o przynajmniej $40 \%$,

- pochodzenie przynajmniej $40 \%$ paliw w lotnictwie ze źródeł odnawialnych i spełnianie warunku niskoemisyjności,

- przesunięcie 50\% międzymiastowego ruchu pasażerskiego na średnie dystanse oraz transportu towarów $\mathrm{z}$ dróg na tory kolejowe i szlaki morskie.

\section{INTRODUCTION}

Recently, the European Commission adopted a comprehensive strategy (Transport 2050) aimed to establish a competitive transport system, in order to: enhance mobility, overcome major barriers in key areas of industry growth, and stimulate employment growth in this sector of the economy. Future plans aim to reduce by $60 \%$ the total carbon dioxide emissions in the transport sector by the year 2050 and as well as lead to a sharp reduction in Europe's dependence on imported oil.

Achieving the aforementioned objectives requires a thorough transformation of the current transport systems. The most important specific objectives for 2050 include:

- cities free of conventional powertrains,

- reducing the emissions associated with marine transport by at least $40 \%$,

- ensuring that at least $40 \%$ of fuel used in aviation is obtained from sustainable sources and compliance with the carbon efficiency requirements,

- shifting $50 \%$ of medium range intercity passenger traffic and freight transit from roads to railway and sea routes. 
W poruszanych aspektach szczególnego znaczenia nabiera przełamanie wieloletniej zależności sektora transportu od oleju napędowego, nie tracąc przy tym sprawności jednostek napędowych pojazdów. Może być to związane z rozwojem nowoczesnych napędów. Podczas projektowania i konstruowania każdego układu napędowego pojazdu, oprócz m.in. dużej wytrzymałości, bierze się pod uwagę także jego właściwości ekologiczne i ekonomiczne (małą emisję substancji toksycznych oraz małą wartość zużycia paliwa). Producenci pojazdów transportu masowego muszą ciagle prowadzić prace $\mathrm{w}$ tych kierunkach, tak by sprostać nie tylko regulacjom prawnym, dotyczącym ekologii eksploatacji pojazdów, lecz również oczekiwaniom klientów (użytkowników).

Na przestrzeni ostatnich kilku lat, w kwestii budowy i modernizacji pojazdów szynowych można zaobserwować szczególnie nasilone działania związane $\mathrm{z}$ ograniczaniem ich szkodliwego oddziaływania na środowisko naturalne oraz zmniejszeniem zużycia energii wykorzystywanej w celu wykonywania założonych zadań przewozowych (rys. 1). W przypadku pojazdów elektrycznych dąży się przede wszystkim do ograniczenia ilości energii pobieranej z sieci trakcyjnej, czy też do wykorzystania energii odzyskiwanej podczas hamowania do zasilania napędów pomocniczych lub przekazywania powrotnego do sieci trakcyjnej. W odniesieniu do pojazdów spalinowych dąży się natomiast m.in. do zmniejszenia emisji toksycznych składników spalin do atmosfery oraz jednostkowego zużycia paliwa i środków smarnych.

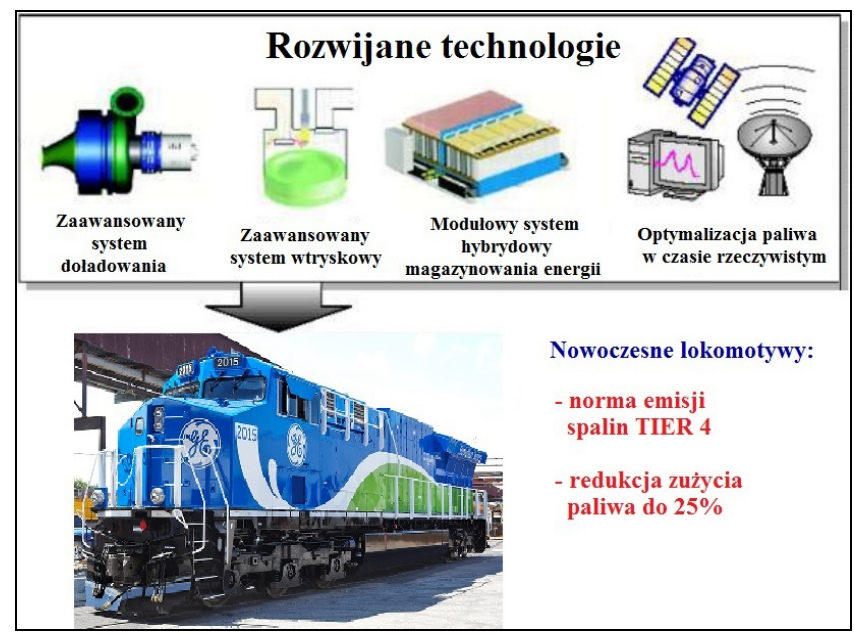

Rys. 1. Przykłady nowoczesnych technologii stosowanych w kolejnictwie [11]

Fig. 1 - Examples of modern technologies used in the rail industry [11]

\section{REDUKCJA ZUŻYCIA PALIWA PRZEZ POJAZDY}

\subsection{Odzysk energii}

$\mathrm{Z}$ powodu istnienia dużej konkurencji między producentami, obserwuje się obecnie szybko postępującą
In the aspects discussed in this paper breaking the long-term dependence of the transport sector on diesel fuel without sacrificing at least the powertrain efficiency of vehicles is of particular importance. This may be related to the development of new drive technology. During the design and construction of each vehicle powertrain, the ecological and economic characteristics (low emission of toxic substances and low fuel consumption) are taken into account along with the usual aspects such as, for example, durability. Manufacturers of mass transit vehicles must carry out continuous research work in these directions, in order to meet not only the legal regulations concerning ecological operation of vehicles, but also the expectations of the clients (the end users). In terms of construction and modernization of rail vehicles increased activities related to the reduction of their environmental impact and reducing the energy consumption used to perform its tasks and transport can be observed, particularly in the last few years (Fig. 1). In the case of electric rail vehicles the aims are primarily the reduction of the amount of power drawn from the catenary, or the use of energy recovered during braking to power auxiliary drives or feeding it back to the grid. In the case of vehicles with combustion engines on the other hand, the aim is to reduce the emissions of toxic exhaust components to the atmosphere and the specific fuel consumption and lubricant use.

\section{REDUCTION OF VEHICLE FUEL CON- SUMPTION}

\subsection{Energy recovery}

Because of the high level of competition among manufacturers, a rapid progress in the evolution of vehicle propulsion systems can currently be observed, which is a desired process, because it will lead to the improvement of the safety and efficiency of freight transport and the reduction of the negative impact of these vehicles on the environment.

The increasing presence of hybrid drive systems in the transport industry can be considered an element of the aforementioned evolution. This means that the coexistence of the primary and secondary power source, for example: in a vehicle intended for mass transit. As a result this entails that a vehicle with a hybrid drive system should be equipped with at least two (sometimes independent) power and drive sources. In the context of currently used solutions, it is assumed that the primary source is most commonly the internal combustion engine, and the secondary in most cases rechargeable batteries with electric engine/motors.

Hybrid systems that are currently available in the transport market, with new ones constantly being introduced, can be divided according to different criteria. For example, according to the criterion of elec- 
ewolucję w układach napędowych pojazdów, która jest procesem pozytywnym, gdyż powoduje poprawę bezpieczeństwa przewozów i efektywności transportu oraz wpływa na zmniejszenie negatywnego oddziaływania tych pojazdów na środowisko naturalne.

Upowszechnianie się $\mathrm{w}$ przemyśle transportowym układów napędu hybrydowego można zaliczyć w poczet wyżej wspomnianej ewolucji. Oznacza to współistnienie pierwotnego i wtórnego źródła napędu, np. w pojeździe przeznaczonym do przewozów masowych. Wiąże się to $\mathrm{z}$ tym, że w pojeździe o układzie napędu hybrydowego powinny znajdować się przynajmniej dwa (czasami niezależne) źródła energii i napędu. W ramach współcześnie stosowanych rozwiązań przyjmuje się, że źródło pierwotne stanowi najczęściej silnik spalinowy, natomiast wtórne - $\mathrm{w}$ większości przypadków akumulatory zasilające silnik/silniki elektryczne.

Układy napędu hybrydowego, aktualnie dostępne na rynku transportowym oraz na niego stale wprowadzane, można podzielić ze względu na różne kryteria. Przykładowo, według kryterium udziału układów napędu elektrycznego w pojeździe wyróżnia się następujące typy [5]: micro hybrid (zastosowanie tzw. systemu start-stop), mild hybrid (składa się z systemu startstop oraz z silnika elektrycznego małej mocy), full hybrid (rozwiązanie, w którym mogą jednocześnie współdziałać ze sobą silnik spalinowy i elektryczny a także możliwy jest odrębny napęd na dowolnym $\mathrm{z}$ tych silników). Należy zwrócić uwagę, że układy napędu hybrydowego w pojazdach ciężarowych, autobusach lub w pojazdach szynowych mają przeważnie konfiguracje zgodne z konfiguracjami pojazdów osobowych, czyli te wymienione wyżej. W pojazdach ciężkich nie ma bowiem wielu dodatkowych rozwiązań tego rodzaju układów.

W przypadku branży szynowej najbardziej zaawansowane projekty wdrażania do użytkowania układów napędu hybrydowego można spotkać w pojazdach, takich jak: trolejbusy, tramwaje i elektryczne zespoły trakcyjne. W odniesieniu do pojazdów trakcji spalinowej prace związane $\mathrm{z}$ wprowadzeniem do eksploatacji układów napędu hybrydowego są jak na razie w mniejszym stadium realizacji i rozwijane przede wszystkim w wysoko uprzemysłowionych krajach świata.

Zastosowanie układów napędu hybrydowego w pojazdach kolejowych trakcji spalinowej umożliwia

uzyskanie przede wszystkim następujących korzyści $[2,4,6]$ :

- odzysk $30 \div 40 \%$ energii wykorzystywanej w procesie hamowania,

- zmniejszenie $20 \div 60 \%$ zużycia oleju napędowego,

- zmniejszenie o $40 \%$ emisji węglowodorów i dwutlenku węgla do atmosfery,

- zmniejszenie o 10\% emisji tlenków azotu i cząstek stałych, tric drive system's participation in the vehicle they can be divided into the following types [5]: micro hybrid (the use of the start-stop system), mild hybrid (composed of the start-stop system and a low power electric motor), full hybrid (a solution where the internal combustion engine and an electric motor can work together as well as where either one can provide propulsion on its own). It should be noted that the hybrid systems in trucks, buses or rail vehicles are generally compliant with the configurations of passenger vehicles, i.e. same as those mentioned above. In heavy vehicles there is in fact a number of additional solutions for such systems.

In the case of the rail industry the most advanced projects of hybrid systems implementation into active operation can be found in such vehicles as trolley buses, trams and electric multiple units. Compared to diesel rail vehicles the work on the introduction of the hybrid drive into service are currently in a lesser stage of development and being developed mainly in the most industrialized countries.

The use of hybrid drive systems in diesel rail vehicles provides primarily the following benefits $[2$, 4, 6]:

- recovery of $30 \div 40 \%$ of the energy used when braking,

- $20 \div 60 \%$ reduced diesel fuel consumption,

- $40 \%$ reduced emissions of hydrocarbons and carbon dioxide into the atmosphere,

- $10 \%$ reduction in the emissions of nitrogen oxides and particulate matter,

- Reduced noise level and vibrations in the cab.

Although hybrid solutions, introduced to improve the "ecological status" of combustion rail vehicles, are still in a relatively early stage of development, companies such as General Electric, Railpower Technologies Corp. and Alstom successfully implemented hybrid locomotives into operation by modernizing older diesel shunters and switchers. For example, in 2007, the company General Electric has built the world's first freight locomotive that could recover energy obtained during braking as a part of their Ecomagination strategy. This energy is stored in highenergy storage units and then used as a secondary power source. That locomotive, named 2010 GE Evolution Hybrid and weighing approximately $207000 \mathrm{~kg}$, can in a year save energy equivalent to that consumed by 160 households. Its operation also reduces emissions of pollutants in the exhaust and the fuel consumption [10].

Energy storage systems for hybrid drives, including modular ones (fig. 2), can be based on lithiumion batteries. Those used in rail vehicles must meet requirements such as the appropriate: energy density, safety, cycle stability, and production quality. Each module contains 12 lithium-ion cells and provides a thermal and electrical connection. It also includes a 
- obniżenie poziomu hałasu i drgań w kabinach sterowniczych.

Mimo, że rozwiązania hybrydowe wprowadzane w celu poprawy „stanu ekologicznego" spalinowych pojazdów szynowych są jeszcze w początkowym stadium rozwoju, takie firmy, jak General Electric, Railpower Technologies Corp czy Alstom z sukcesem wdrożyły do eksploatacji lokomotywy hybrydowe, modernizując starsze wiekiem spalinowe lokomotywy manewrowe i liniowe. Przykładowo, w roku 2007 wspomniana firma General Electric w ramach strategii Ecomagination zbudowała pierwszą na świecie lokomotywę towarową przetwarzającą energię uzyskaną podczas hamowania. Energia ta magazynowana jest w wysokowydajnych zasobnikach energii i wykorzystywana następnie na potrzeby własne jako źródło energii dodatkowej. Opisywana lokomotywa o nazwie 2010 GE Evolution Hybrid i masie około 207000 kg może zaoszczędzić w ciagu roku tyle energii, ile zużywa 160 gospodarstw domowych. Jej eksploatacja zmniejsza ponadto emisję zanieczyszczeń w spalinach oraz zużycie paliwa [10].

Systemy magazynowania energii dla układów napędu hybrydowego, w tym modułowe (rys. 2), oparte moga być na akumulatorach litowo-jonowych. Te użytkowane w pojazdach trakcyjnych muszą spełniać takie wymogi, jak gęstość energii, bezpieczeństwo użytkowania, stabilność cykli pracy, jakość wykonania. Każdy moduł zawiera 12 ogniw litowo-jonowych i zapewnia ich połączenie cieplne i elektryczne. Zawiera on również układ pomiarowy do monitorowania stanu poszczególnych ogniw. Zastosowanie różnych połączeń ogniw (szeregowe, równoległe) pozwala uzyskać akumulatory energii o różnych wartościach mocy i gęstości energii. Przykładowo 15 połączonych szeregowo modułów daje całkowitą wartość energii wynoszącą około $92 \mathrm{kWh}$ i moc szczytową $552 \mathrm{~kW}$ [12].

W aspekcie odzysku energii z pojazdów coraz bardziej popularne staje się wykorzystanie generatorów termoelektrycznych TEG (thermoelectric generator) w układach wylotowych spalin. Odzysk energii ze spalin nabiera szczególnego znaczenia, jeśli chodzi o lokomotywy spalinowe, dysponujące silnikami o dużej mocy i objętości skokowej, a tym samym o dużym wydatku gazów wylotowych. Większość rozwiązań istniejących na rynku motoryzacyjnym i kolejowym jest jednak dopiero na etapie badań $\mathrm{w}$ formie prototypów (rys. 3).

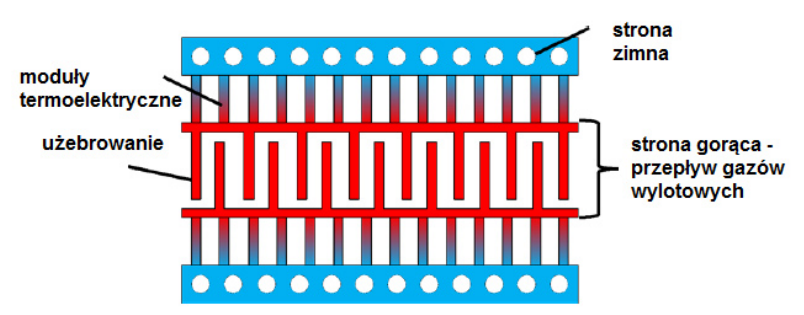

measurement system to monitor the status of individual cells. The use of different combinations of cells (serial, parallel) allows for energy batteries with different power and energy density. For example, 15 modules connected in series gives the total amount of energy of about $92 \mathrm{kWh}$ and peak power of $552 \mathrm{~kW}$ [12].

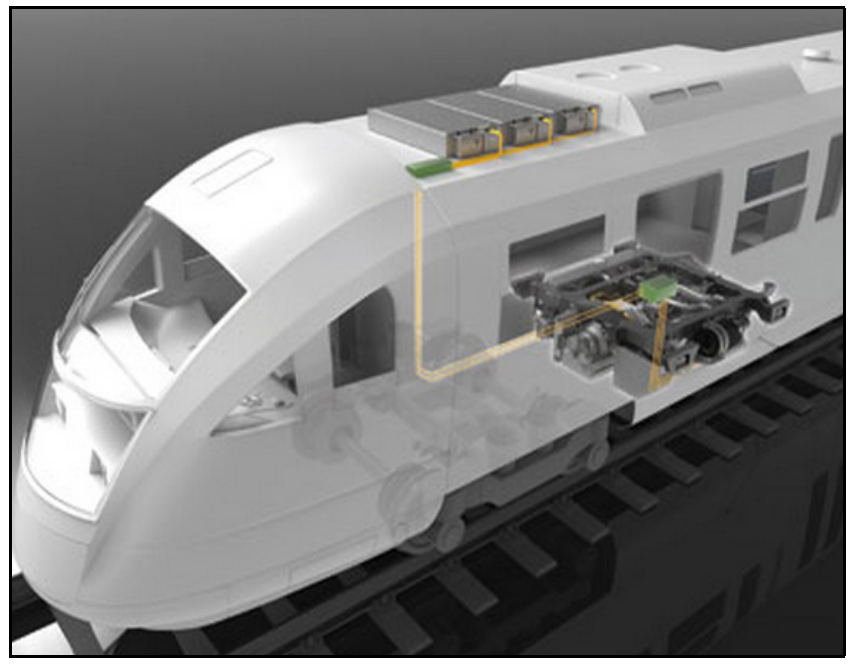

Rys. 2. Modułowy system magazynowania energii w trakcyjnych napędach hybrydowych [12]

Fig. 2 - Modular Energy storage system in hybrid rail vehicles [12]

In the aspect of energy recovery in vehicles it is increasingly more popular to use thermoelectric generators (TEG) in their exhaust systems. Energy recovery from the exhaust gases is of particular importance for high-power diesel engines with a large displacement volume, and thus a high flow of the exhaust gas. Most of the existing solutions in the automotive and the rail markets, however, are only at the stage of research and in the form of prototypes (Fig. 3).

\subsection{Economic operation of internal combustion engines}

An important aspect affecting the improvement, in terms of energy consumption and traffic exhaust emissions, of the use of motor vehicles is using the principles of eco-driving, meaning an appropriate purposes of this analysis (Fig. 5).

Rys. 3. Koncepcja urządzenia do odzysku energii z ciepła odpadowego oraz układ wylotowy silnika lokomotywy TRAXX DE ME firmy Bombardier [3]

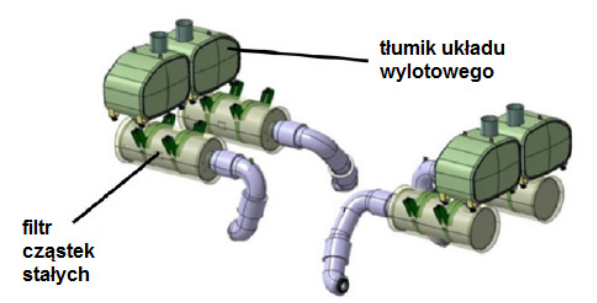

Fig. 3 - The concept of an energy recovery device for waste heat in the exhaust system of engine locomotives TRAXX DE ME by Bombardier company [3] 


\subsection{Ekonomiczne sterowanie silnikami spalino- wymi}

Istotnym rozwiązaniem, $\mathrm{w}$ aspektach energochłonności ruchu i emisji zanieczyszczeń w spalinach wpływającym na usprawnienie użytkowania pojazdów silnikowych, jest stosowanie zasad eco-drivingu, czyli odpowiedniego sterowania jednostkami napędowymi. Pojęcie jazdy ekologicnej pojawiło się i funkcjonuje w branży transportowej stosunkowo niedawno. Jak twierdzą twórcy tego stylu jazdy stosowanie w praktyce przez kierowców pewnych reguł (zasad) skutkuje najmniejszym zużyciem paliwa, a jednocześnie w najmniejszym stopniu wpływa na zanieczyszczenie środowiska naturalnego.

W przedstawionych poniżej wynikach badań rozpatruje się między innymi zagadnienie emisji dwutlenku węgla do atmosfery w odniesieniu do pojazdów ciężkich typu HDV (Heavy Duty Vehicle). Na podstawie wielkości emisji $\mathrm{CO}_{2}$ liczone jest przebiegowe zużycie paliwa przez pojazdy - tzw. metoda bilansu węgla. W szczególności poruszono aspekt kształtowania dynamiki jazdy autobusem miejskim w zakresie od jego zatrzymania (np. postoju na przystanku) do uzyskania stałej prędkości jazdy. Tego rodzaju pomiary emisji zanieczyszczeń, czyli w dynamicznych i nieustalonych warunkach pracy silnika, mają istotne znaczenie dla badań właściwości ekologicznych pojazdów [7, 8]. Warunki takie są wprawdzie charakteryzowane w silnikowych dynamicznych testach badawczych [9], nie odzwierciedlają one jednak wiarygodnie rzeczywistych warunków eksploatacji różnego typu pojazdów. Przed przystapieniem do analizy wpływu dwóch różnych sposobów uzyskiwania tej samej prędkości jazdy badanym autobusem miejskim na emisję $\mathrm{CO}_{2}$, dla zobrazowania wspominanej różnicy $\mathrm{w}$ dynamice rozpędzania obiektu badawczego do $\mathrm{V}=35 \mathrm{~km} / \mathrm{h}$ przez dwóch kierowców (oznaczonych na rysunkach jako A i B), sporządzono przebiegi przyspieszenia uzyskiwanego przez ten pojazd (rys. 4). Maksymalne chwilowe przyspieszenie autobusu dla przejazdów wykonywanych przez kierowcę A mieści się w zakresie 1,1-1,3 $\mathrm{m} / \mathrm{s}^{2}$, natomiast dla przejazdów wykonywanych przez kierowcę $\mathrm{B}$ jest dużo większe, przyjmując wartości $\mathrm{w}$ przedziale $1,6-1,8 \mathrm{~m} / \mathrm{s}^{2}$. Jako wyznacznik dynamiki rozpędzania autobusu miejskiego przyjęto na potrzeby przedmiotowej analizy również średnie przyspieszenie dla całego okresu rozpędzania pojazdu (rys. 5).

a)

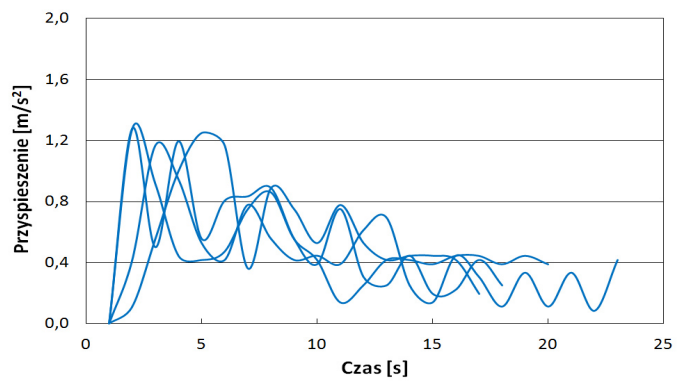

control of drive units. The concept of eco-driving emerged and began functioning in the transport industry relatively recently. As the creators of this driving style claim adherence to certain rules (principles) by drivers when operating vehicles results in the lowest fuel consumption, and thus having the least impact on the environment.

The test results presented below consider, among others, the issue of carbon dioxide emissions into the atmosphere in relation to heavy duty vehicles (HDV, the mileage and fuel consumption of these vehicles is calculated based on $\mathrm{CO}_{2}$ emissions - using what is known as carbon balance method). In particular, the aspect of shaping the driving dynamics of an urban municipal bus from stationary (e.g. stopping at the bus stop) to the standard cruising speed. This kind of measurement of emissions, i.e.: dynamic and transient operating conditions, are important in terms of research into the ecological properties of vehicles $[7,8]$. Such conditions are also characterized in the dynamic engine tests [9], but they do not reliably reflect the real operating conditions of various types of vehicles.

Before analyzing the impact of two different ways of reaching the same cruising speed of the tested city bus on the $\mathrm{CO}_{2}$ emissions, to illustrate the aforementioned difference in the dynamics of accelerating the test vehicle to $\mathrm{V}=35 \mathrm{~km} / \mathrm{h}$ by two different drivers (shown in Figures A and B), acceleration parameters obtained by the vehicle have been determined (Fig. 4). The maximum instantaneous acceleration of the bus when driven by the driver $\mathrm{A}$ is in the range of $1.1-1.3 \mathrm{~m} / \mathrm{s}^{2}$, and when driven by the driver B became much larger, the values were in the range of 1.6-1.8 $\mathrm{m} / \mathrm{s}^{2}$. The average acceleration from the whole period of acceleration of the vehicle was taken and adopted as an indicator of the acceleration dynamics for the purposes of this analysis (Fig. 5).

b)

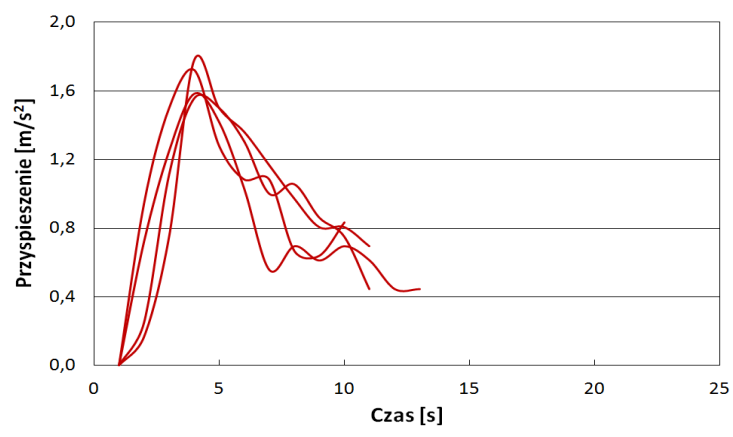

Rys. 4. Przebieg chwilowego przyspieszenia uzyskiwanego przez autobus miejski podczas jego rozpędzania do $\mathrm{V}=35 \mathrm{~km} / \mathrm{h}$ [1]: a) kierowca $\mathrm{A}, \mathrm{b}$ ) kierowca $\mathrm{B}$

Fig. 4 - The function of the instantaneous acceleration experienced by the city bus during acceleration to $\mathrm{V}=35 \mathrm{~km} / \mathrm{h}$ [1]: a) driver A, b) driver B 
Analizując prezentowane wyniki badań przeprowadzonych $w$ rzeczywistych warunkach ruchu, można przyjąć, że uśredniona wartość emisji drogowej $\mathrm{CO}_{2}$ uzyskana $\mathrm{w}$ trakcie prowadzenia autobusu miejskiego przez kierowcę B jest o około $1000-1500 \mathrm{~g} / \mathrm{km}$ większa, niż w przypadku kierowcy A (rys. 5). Wynika to m.in. z innych obciążeń silnika spalinowego, zadawanych przez obu kierowców (wywieranie wpływu na większe bądź mniejsze zapotrzebowanie energetyczne - wielkość dawki paliwa).

Tytułem uzupełnienia należy wskazać, że zadawanie prędkości jazdy - sterowanie obciążeniem silnika - w przypadku kierowcy B odbywało się w wyniku praktycznie maksymalnego naciskania na pedał przyspieszenia. Było to korzystniejsze ze względu na zachowanie większej powtarzalności co do sposobu rozpędzania autobusu, wobec techniki jazdy preferowanej przez kierowcę A.

$\mathrm{Na}$ potrzeby podjętych w artykule analiz wykonano także pomiary toksyczności spalin $\mathrm{w}$ rzeczywistych warunkach ruchu trzech samochodów ciężarowych. Były nimi: MAN TGL z zabudową plandekową (pojazd HDV1), Scania 94G 220 z wywrotką trójstronną (HDV2) oraz Scania R z naczepa kurtynową (HDV3). Badania wykonano na terenie aglomeracji poznańskiej, na trasie wiodącej z Poznania do Wrześni i z powrotem oraz w mieście Koło i jego okolicach. Sterowanie silnikami pojazdów badawczych odbywało się według trzech sposobów określonych jako: eco-driving, jazda normalna, jazda agresywna. Definicje poszczególnych sposobów eksploatacji pojazdu przyjęto następująco (rys. 6):

- eco-driving - umiarkowane przyspieszanie, hamowanie silnikiem - redukcja biegów w trakcie np. dojazdu do sygnalizatora świetlnego,

- jazda normalna - powolne przyspieszanie, stosowanie jazdy wybiegiem (bieg luzem i jałowy silnika) $\mathrm{w}$ trakcie np. dojazdu do sygnalizatora świetlnego,

- jazda agresywna - dynamiczne przyspieszanie, dojazd do sygnalizatora świetlnego - hamowanie $\mathrm{z}$ dużej prędkości w końcowej fazie dojazdu.

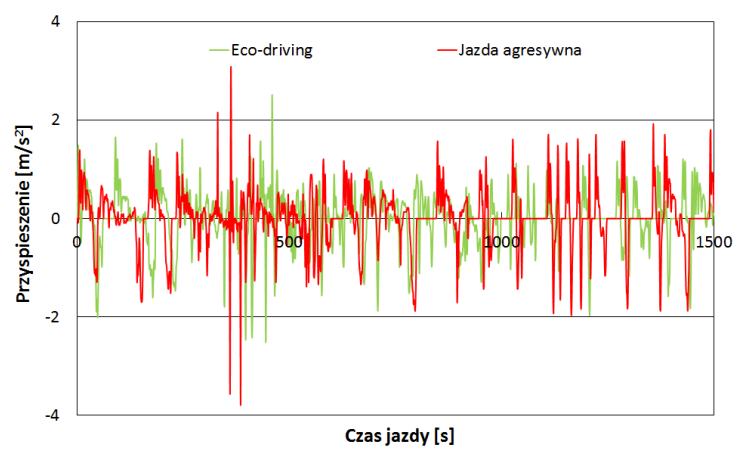

Rys. 6. Przyspieszenie uzyskiwane przez pojazd HDV1

Fig. 6 - Acceleration recorded for the HDV1 vehicle
When analyzing the results of the research carried out in real driving conditions, it can be assumed that the average value of road $\mathrm{CO}_{2}$ emissions obtained when the city bus was driven by driver $\mathrm{B}$ is about 1000 to $1500 \mathrm{~g} / \mathrm{km}$ higher than in the case of driver A (Fig. 5). This is due to different loads of the internal combustion engine, exerted by both drivers (causing a larger or smaller energy requirement - the amount of fuel used).

To supplement the information, it should be noted that the reference speed - engine load control was done by pressing the accelerator pedal down almost entirely in the case of driver B. It was better due to obtaining a greater repeatability as to the manner of bus acceleration, compared to the driving style used by the driver $\mathrm{A}$.

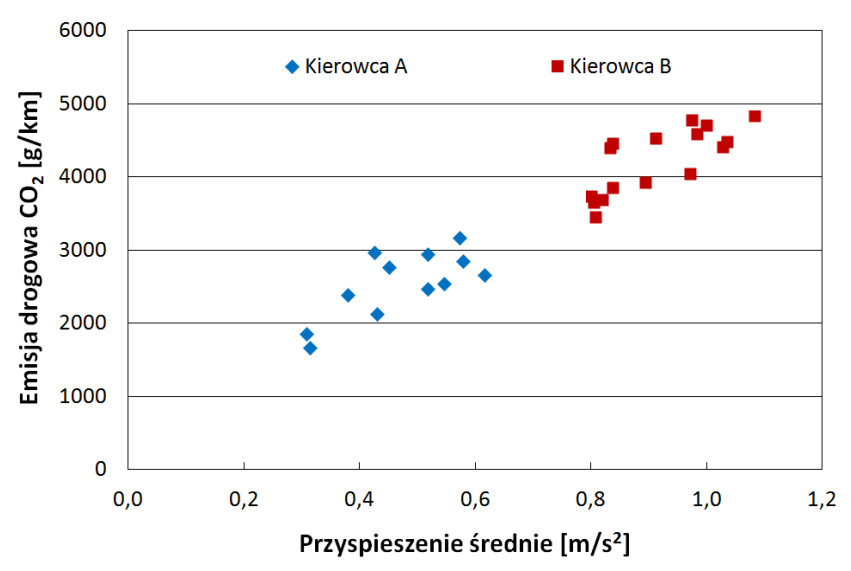

Rys. 5. Emisja dwutlenku węgla uzyskana w wyniku pracy poszczególnych kierowców [1]

Fig. 5 - Carbon dioxide emissions obtained from the test with the two drivers [1]

For the purposes of the analysis undertaken in the article measurements of exhaust emissions in real traffic conditions of three trucks were also performed. These were: MAN TGL with tarp cover (vehicle HDV1), Scania 94G 220 with a three-way tipper (HDV2) and Scania R with side curtains (HDV3). The research was conducted within the city agglomeration, the route leading from Poznan to Września and back, as well as in and around the town Koło. The vehicle engines were used with three defined driving styles: eco-driving, normal driving, and aggressive driving. Definitions of the various vehicle driving styles are as follows (Fig. 6):

- eco-driving - moderate acceleration, engine braking - using downshift when, for example, approaching a traffic light,

- normal driving - slow acceleration, freewheel driving (neutral gear and idle) when, for example, approaching a traffic light,

- aggressive driving - dynamic acceleration, braking from high speed in the final phase when approaching a traffic light. 
Określone za pomocą specjalistycznej mobilnej aparatury pomiarowej typu PEMS (Portable Emission Measurement System) stężenie poszczególnych szkodliwych składników gazowych w spalinach posłużyło do obliczenia ich emisji drogowej, a następnie przebiegowego zużycia paliwa przez dany pojazd. Wartości tego zużycia, wyznaczone dla całych tras przejazdu, zaprezentowano na rysunku 7.

W związku z tym, że obiekty badań były wyposażone w różne układy napędowe (moc silnika, klasa emisyjna) dostrzegalne jest znaczne zróżnicowanie zarówno w emisji drogowej substancji szkodliwych, jak i przebiegowym zużyciu paliwa przez poszczególny badany pojazd z grupy HDV (rys. 7). Ponadto badane pojazdy cechowały się różną masą własną i przewożonym ładunkiem. Dla przykładu przejazdy pojazdem oznaczonym jako HDV2 odbywały się „na pusto” (bez ładun$\mathrm{ku}$ ), a przejazdy pojazdem HDV3 z ładunkiem o masie około $25.000 \mathrm{~kg}$. Dla wszystkich obiektów badań daje się jednak zauważyć podobny wpływ stosowanego przez kierowcę różnego sposobu jazdy. Uzyskano oszczędności w zużyciu paliwa oraz zmniejszenie emisji związków szkodliwych spalin na poziomie kil$\mathrm{ku}$ procent (eco-driving względem jazdy normalnej) oraz pogorszenie właściwości ekologicznych i ekonomicznych pojazdu $\mathrm{w}$ wyniku stosowania jazdy agresywnej o kilkanaście procent.

\section{PODSUMOWANIE}

Prace prowadzone $\mathrm{w}$ ostatnich latach $\mathrm{w}$ zakresie transportu masowego (samochodowego i kolejowego) zwracają szczególną uwagę na ograniczenie jego szkodliwego oddziaływania na środowisko naturalne człowieka - emisję toksycznych zanieczyszczeń w spalinach. Biorąc pod uwage fakt wykorzystywania głównie paliw kopalnych jako źródła energii w drogowych pojazdach użytkowych i spalinowych pojazdach trakcyjnych, należy również zdecydowanie dążyć do zmniejszenia ich zużycia (z uwagi na konieczność redukcji emisji $\mathrm{CO}_{2}$ do atmosfery), a tym samym zwiększenia efektywności przewozów, zarówno w ruchu pasażerskim, jak i towarowym.

W zakresie zbioru środków umożliwiających poprawę efektywności w przewozach osób i ładunków, realizowanych za pomocą pojazdów drogowych i szynowych, mieści się nowoczesny tabor. Nowe pojazdy trafiające $\mathrm{z}$ linii produkcyjnych do firm transportowych są w stanie zapewnić nie tylko duży poziom tej efektywności, lecz także bezpieczeństwa tych przewozów. Wiąże się to m.in. ze stosowaniem $\mathrm{w}$ środkach transportu masowego nowoczesnych i wydajnych układów napędowych, w tym hybrydowych, które między innymi były istotą przedmiotowego artykułu.

Innym $\mathrm{z}$ rozwiązań mających na celu zmniejszenie energochłonności ruchu pojazdów jest pełna modernizacja użytkowanych dotychczas lokomotyw liniowych
The concentration of each of the harmful gaseous components in the exhaust gas determined with the use of special mobile measuring equipment PEMS (Portable Emission Measurement System) was used to calculate the road emissions, and the fuel consumption of a vehicle. The values of this consumption, determined for the entire routes, is shown in Figure 7.

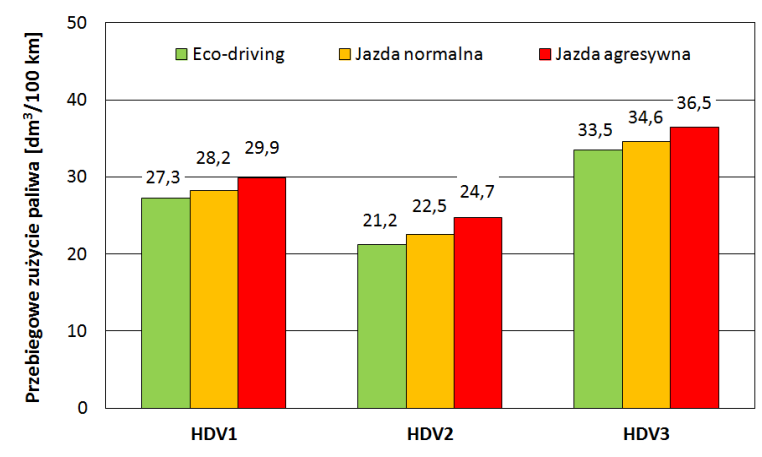

Rys. 7. Przebiegowe zużycie paliwa przez poszczególny pojazd typu HDV

Fig. 7 - Fuel consumption by individual HDV type vehicles

Because the tested vehicles were equipped with various drive systems (power output, emission class) a large variation in both pollutant emissions, and fuel consumption between the tested HDV vehicles can be seen (Fig. 7). In addition, the tested vehicles were characterized by different curb weight and the transported cargo. For example, the routes of the vehicle marked as HDV2 were done when "empty" (without any cargo), and the routes of vehicle HDV3 when laden with a mass of $25000 \mathrm{~kg}$. However a similar effect of the driver using different driving styles can be observed for all the tested vehicles. Savings in fuel consumption and reduced emissions of harmful exhaust components on a level of a few percent has been achieved (eco-driving in relation to the normal driving) and the deterioration of ecological and economical vehicle parameters by several percent when using aggressive driving.

\section{CONCLUSIONS}

The research work carried out in the recent years in the field of mass transport (both road and rail) pays particular attention to reducing its harmful effects on the environment - the release of toxic pollutants in the exhaust gas. Given that road vehicles and diesel rail vehicles use mainly fossil fuels as a source of energy the reduction of their fuel consumption (due to the need to reduce the $\mathrm{CO}_{2}$ emissions into the atmosphere), thus increasing the efficiency of both on passenger and freight transport, should also be vigorously pursued.

One of the measures to improve the efficiency of passenger and cargo transport carried out by road and rail vehicles is fleet modernization. New vehicles 
i manewrowych. Mimo wysokich początkowych kosztów wprowadzania nowych systemów (np. generatory TEG), poniesione nakłady finansowe szybko się zwracają, a przeważającą korzyścią jest zmniejszenie zużycia energii. Istotne efekty $\mathrm{w}$ poruszanych aspektach ekonomicznych można także uzyskać w wyniku stosowania właściwego sterowania silnikiem pojazdów transportu masowego (zadawanie obciążenia).

\section{Bibliografia}

[1] Bajerlein M., Andrzejewski M., Dobrzyński M., Rymaniak Ł.: Wplyw sposobu rozpędzania autobusu miejskiego na emisję dwutlenku węgla, Badania pojazdów - opracowanie monograficzne. Praca zbiorowa pod red. W. Mitiańca, Politechnika Krakowska, Kraków 2014, s. 193-202.

[2] Ekologiczna moc hybrydy. Materiat reklamowy firmy Railpower Technologies Corp.

[3] Heghmanns A., Wilbrecht S., Beitelschmidt M., Geradts K.: Parameter optimization and operating strategy of a TEG system for railway vehicles, Journal of ELECTRONIC MATERIALS, Vol. 45, No. 3, 2016.

[4] Hybridteknik $i$ nya tidens lok (Hybrids bringing a new era for locomotives). Materialy informacyjne, 03.2007.

[5] Merkisz J., Pielecha I., Alternatywne napędy pojazdów. Wydawnictwo Politechniki Poznańskiej, Poznań 2006.

[6] Multi Gensets Locomotives for Canadian Railways. Rail - Government Interface, 2007 (prezentacja firmy svensk tagtechnik AB (Szwecja). delivered from the production lines to transport companies are able to provide not only high level of efficiency, but also increase the transport safety. This involves for example the use of modern and efficient powertrains in the means of mass transportation, including hybrids, which are one of the issues discussed in this article.

Another solution aimed at reducing the energy demand of traffic is full modernization of operated switching and shunting locomotives. Despite the high initial cost of introducing new systems (e.g. TEG) the financial investment quickly pays off, and the overwhelming benefit is the reduction of energy consumption. Significant results in the discussed economic aspects can also be obtained by the use of proper engine control systems of mass transportation vehicles (the exerted load).

[7] Rapone M., Ragione L., Meccariello G.: Characterization of real-world bus driving behavior for emission evaluation. SAE Technical Paper Series 2007-24-0112.

[8] Walsh M.: Global trends in motor vehicle pollution control: a 2011 update. Part 1. Combustion Engines/Silniki Spalinowe, No. 2/2011 (145), 106117.

[9] Worldwide emissions standards: passenger cars, light duty vehicles and heavy duty vehicles. Delphi Innovation for the Real World, 2015.

[10] http://railworksamerica.com/ (dostęp z dnia 13.02.2016).

[11] http://wwwl.eere.energy.gov/vehiclesandfuels/pdfs/ hvso_2006/22_salasoo.pdf

[12] www.sensor-technik.de 